JURNAL ILMIAH KOMPUTER GRAFIS, Vol.13, No.1, Juli 2020, pp. 50 - 60

p-ISSN : 1979-0414(print)

e-ISSN : 2621-6256 (online)

http://journal.stekom.ac.id/index.php/pixel

\title{
METODE PEMBELAJARAN BACA TULIS ALQUR'AN \\ DI SMP ISLAM UNGARAN
}

Rudjiono $^{1}$, Achmad Zainudin ${ }^{2,}$ Ismail $^{3}$

'STEKOM,rudjiono@stekom.ac.id

2STEKOM,Zaenudin@stekom.ac.id

${ }^{3}$.SMP ISLAM UNGARAN, smpislamungaran@yahoo.co.id

${ }^{1}$ Jl. Majapahit 605, Semarang, telp/fax : 024-6717201-02

${ }^{2} J 1$. Majapahit 605, Semarang, telp/fax : 024-6717201-02

${ }^{3}$ Jl. Kauman Selatan No.1 Ungaran, telp : (024) 6925169

\section{ARTICLE INFO}

\section{Article history:}

Received 31 Juli 2020

Received in revised form

1 Agustus 2020

Accepted 10 Agustusi

2020

Available online 18

Agustusi 2020

\section{ABSTRACT}

Basically, the principles of Al-Qur'an learning can be carried out using various methods, all of which have the same goal, namely so that children can read the Al-Qur'an properly and correctly. The low motivation of students in learning the Qur'an is still one of the reasons for the low quality of education, especially in the ability to read the Qur'an. One of the efforts to increase motivation to learn to Read and Write the Qur'an is the use of online methods during the Covidpandemic. 19 can be carried out by educators or teachers in the reading and writing subject of the Koran which is the basis of learning in Islam

The low motivation of students in learning Al-Qur'an is still one of the reasons for the low quality of education, especially in the ability to read Al-Qur'an. So it can be said that motivation and learning achievement are directly proportional to the learning methods developed. One of the efforts to increase the motivation to learn to read and write al-quran is to use appropriate methods that can be used by educators or teachers in reading and writing al-Qur'an subjects which are the basis of learning in Islam.

Keyword :baca tulis alqur'an,tajwid

\section{A. Pendahuluan}

Dalam mendidik agama pada siswa jenjang Sekolah Menengah Pertama diperlukan pendekatan pendekatan tertentu, diantaranya melalui pendekatan anak didik atau siswa melalui kegiatan bimbingan, latihan dan pengajaran keagamaan, termasuk didalamnya mengarahkan, mendorong, dan memberi semangat kepada mereka agar mau mempelajari ajaran agamanya melalui baca tulis Al- Qur'an (BTA)

Pendidikan merupakan interaksi antara orang dewasa dengan orang yang belum dapat menunjang perkembangan manusia yang berorientasikan berhubungan dengan usaha pengembangan kehidupan manusia.

Dalam Al-Qur'an dan hadits Nabi SAW dinyatakan bahwa agama (tauhid/keimanan kepada Allah SWT) merupakan suatu fitrah atau potensi dasar manusia (anak). Sedangkan tugas pendidik adalah mengembangkan dan membantu tumbuh kembangnya fitrah tersebut pada manusia (anak). Sesuai dengan firman Allah SWT dalam surat Ar Ruum ayat 30, yang artinya: "Maka hadapkanlah wajahmu dengan lurus kepada agama Allah; (tetaplah atas) fitrah Allah yang Telah menciptakan manusia menurut fitrah itu. Tidak ada peubahan pada fitrah Allah. (Itulah) agama yang lurus; tetapi kebanyakan manusia tidak mengetahui”.[1] 
JURNAL ILMIAH KOMPUTER GRAFIS, Vol.13, No.1, Juli 2020, pp. 50 - 60

p-ISSN : 1979-0414(print)

e-ISSN : 2621-6256 (online)

http://journal.stekom.ac.id/index.php/pixel

Al-Qur'an adalah kalam Allah SWT yang diturunkan (diwahyukan) kepada Nabi Muhammad SAW melalui perantaraan malaikat Jibril, yang merupakan mukjizat, yang diriwayatkan secara mutawtir, yang ditulis di mushaf, dan membacanya adalah ibadah.[2]

Al Qur'an ialah Kitab Suci yang merupakan sumber utama dan pertama ajaran Islam, menjadi petunjuk kehidupan umat manusia diturunkan Allah kepada Nabi Muhammad S.a.w. sebagai salah satu rahmat yang tak ada taranya bagi alam semesta. Di dalamnya terkumpul wahyu Ilahi yang menjadi petunjuk, pedoman dan pelajaran bagi siapa yang mempercayai serta mengamalkannya. Karena itu setiap orang yang mempercayai Al Qur'an, akan bertambah cinta kepadanya, cinta untuk membacanya, untuk mempelajarinya dan memahaminya serta mengamalkan dan mengajarkannya.

Al Qur'an diturunkan kepada Nabi Muhammad S.a.w. sekian abad yang lalu. Persoalan yang muncul dan menjadi rumit ketika jarak waktu, tempat, budaya antara pembaca dan teks demikian jauh. Al Qur'an yang diturunkan di Arab dan berbahasa Arab akan berbeda ditangkap oleh umat muslim bangsa Indonesia secara kultur. Akan tetapi, Al Qur'an bagaimanapun adalah Kitab Allah SWT. untuk semua manusia yang menandung nilainilai universal yang kontekstual untuk segala zaman. Untuk mengetahui nilai-nilai yang universal tersebut maka Al Qur'an perlu dipelajari.

Setiap insan dianjurkan untuk mengajarkan Al Qur'an kepada dirinya sendiri, keluarga, dan orang lain. Disamping itu juga harus memikirkan, merenungkan, memahami dan mengamalkannya dalam kehidupan seharihari. Untuk mengatasi hal itu maka tentunya harus bisa membaca Al Qur'an dengan baik dan benar. Bagi yang belum bisa membaca Al Qur'an, tentunya sulit untuk mempelajari Al Qur'an. Oleh karena itu, diperlukan cara membaca $\mathrm{Al}$ Qur'an yang tidak menyulitkan terutama bagi pemula atau anak yang masih kecil.

Prinsip pengajaran Al-Qur'an pada dasarnya dapat dilakukan dengan berbagai macam metode, yang semuanya memiliki tujuan yang sama yaitu agar anak-anak dapat membaca Al-Qur'an dengan baik dan benar. Metode adalah cara yang digunakan untuk melaksanakan suatu pekerjaan agar tercapai sesuai dengan yang dikehendaki.[3] Dalam proses belajar mengajar metode merupakan faktor yang sangat dominan dalam menentukan keberhasilan pembelajaran. Seorang pendidik atau guru diharapkan memiliki berbagai metode yang tepat serta kemampuan dalam menggunakan metode yang akan digunakan dalam proses pembelajaran.

Metode pembelajaran Al-Qur'an pada hakekatnya adalah mengajarkan Al-Qur'an pada anak yang merupakan suatu proses pengenalan Al-Qur'an tahap pertama dengan tujuan agar siswa mengenal huruf sebagai tanda suara atau tanda bunyi. Pengajaran membaca Al-Qur'an tidak dapat disamakan dengan pengajaran membaca dan menulis di sSekolah Menengah Pertama, karena dalam pengajaran Al-Qur'an, anak-anak belajar huruf dan kata-kata yang tidak mereka pahami artinya. Yang paling penting dalam pembelajaran membaca Al-Qur'an adalah keterampilan membaca Al-Qur'an dengan baik sesuai dengan kaidah yang disususun dalam ilmu Tajwid.[4]

Salah satu kesulitan membaca Al-Qur'an bagi anak-anak adalah karena ayat-ayatnya terdapat kalimat yang panjang sehingga mengakibatkan kurang lancar, bahkan tidak faasih dalam membaca. Kesulitan tersebut diakibatkan karena pada tingkat dasar belum sepenuhnya memahami ilmu tajwid, dan biasanya para guru mengajarkan secara praktis, sehingga seringkali anak sekedar menghafal saja. Hal tersebut di atas juga banyak dialami oleh anak didik yang masih duduk dibangku tingkat dasar. Maka bagi guru perlu menggunakan metode yang tepat dan efisien dalam mengajarkan membaca Al Qur'an.

Rendahnya motivasi siswa dalam belajar al-Qur'an masih merupakan salah satu penyebab rendahnya mutu pendidikan terutama dalam kemampuan membaca al-Qur'an. Salah satu upaya untuk meningkatkan motivasi belajar Baca Tulis al-Qur'an adalah dengan penggunaan metode yang sesuai yang dapat dilakukan oleh guru Baca Tulis al-Qur'an dalam kelas.

Dalam mendidik agama pada siswa jenjang sSekolah Menengah Pertama diperlukan pendekatan pendekatan tertentu, diantaranya melalui pendekatan keagamaan. Pendekatan keagamaan ialah bagaimana cara pendidik memproses anak didik atau siswa melalui kegiatan bimbingan, latihan dan pengajaran keagamaan, termasuk didalamnya mengarahkan, mendorong, dan memberi semangat kepada mereka agar mau mempelajari ajaran agamanya melalui baca tulis Al- Qur'an (BTA), serta taat dan mempunyai cita rasa beragama Islam.[5]

Pendidikan merupakan interaksi antara orang dewasa dengan orang yang belum dapat menunjang perkembangan manusia yang berorientasikan pada nilai-nilai dan pelestarian serta perkembangan kebudayaan yang berhubungan dengan usaha pengembangan kehidupan manusia.

Anak didik adalah makhluk yang memiliki kreatifitas dan serba aktif yang menuntut agar dalam pendidikan anak benar-benar dibimbing dan diarahkan agar ia dengan sendirinya juga menampakkan kreatifitasnya. Di dalam proses belajar mengajar anak harus diperhatikan dan diposisikan sesuai dengan kemampuannya, serta pendidikan hendaknya lebih bersifat menolong berkembangnya pikiran kritis, tidak hanya berupa pemberian materi pelajaran yang tidak memenuhi kepada apa yang dibutuhkan anak.[6]

BTA adalah bagian materi Pendidikan Agama Islam di Sekolah Menengah Pertama yang selama ini kurang mendapat perhatian yang lebih besar, padahal banyak sekali masyarakat yang mengeluh bahwa lulusan SMP Islam 
JURNAL ILMIAH KOMPUTER GRAFIS, Vol.13, No.1, Juli 2020, pp. 50 - 60

p-ISSN : 1979-0414(print)

e-ISSN : 2621-6256 (online)

http://journal.stekom.ac.id/index.php/pixel

banyak yang belum dapat membaca Al-Qur'an secara benar sesuai dengan ilmu tajwid. Hal ini juga didukung dengan rendahnya prestasi BTA siswa, terutama pada materi membaca dan menulis huruf hijaiyah yang sudah mulai dikenalkan pada kelas II Sekolah Menengah Pertama. Seharusnya ini menjadi kekhawatiran semua guru Agama Islam, karena diharapkan pendidikan SMP adalah pembentukan diri anak. Akan sangat sulit sekali ketika anak tidak menguasai BTA sejak dini untuk dapat membaca Al-Qur'an secara baik dan benar. Kritikan dan keluhan masih sering dilontarkan oleh masyarakat dan para orang tua siswa. Banyaknya anak yang belum mampu membaca Al-quran dengan baik dan benar, belum mampu menulis serta belum mampu memahami dan mengamalkan isinya.

Di SMP Islam Ungaran kemampuan siswa dalam membaca Al Qur'an masih rendah, terutama belum sesuai dengan kaidah ilmu tajwid. Hal ini dapat diketahui bahwa hasil belajar pada tahun sebelumnya ketuntasan belajar secara klasikal belum tercapai. Kondisi tersebut bukan semata-mata karena daya serap siswa yang rendah, tetapi lebih banyak faktor yang mempengaruhinya. Bisa jadi karena metode pembelajaran yang kurang tepat, model pembelajaran kurang menarik, atau mungkin karena faktor kesiapan siswa dakam menerima materi pelajaran yang kurang maksimal.

Namun dari beberapa faktor tersebut, berdasarkan pengamatan awal yang peneliti lakukan terdapat kecenderungan yang mengarah pada faktor metode pembelajaran yang harus diperbaiki. Dimana metode yang digunakan sebelumnya sebatas pada teori, peran aktif siswa kurang diperhatikan, sehingga hasil pembelajaran BTA belum maksimal. Selanjutnya untuk mengetahui bagaimana kemampuan membaca Al Qur'an siswa SMP Islam Ungaran terutama dalam mempraktikkan bacaan ayat-ayat Al Qur'an yang baik dan benar sesuai dengan tuntunan ilmu tajwid maka diperlukan suatu penelitian ilmiah

Bertitik tolak dari hal tersebut penulis mencoba untuk mengadakan penelitian yang hasilnya akan dituangkan dalam skripsi yang berjudul: "Metode Pembelajaran BTA di SMP Islam Ungaran".

Anak didik adalah makhluk yang memiliki kreatifitas dan serba aktif yang menuntut agar dalam pendidikan anak benar-benar dibimbing dan diarahkan agar ia dengan sendirinya juga menampakkan kreatifitasnya. Di dalam proses belajar mengajar anak harus diperhatikan dan diposisikan sesuai dengan kemampuannya, serta pendidikan hendaknya lebih bersifat menolong berkembangnya pikiran kritis, tidak hanya berupa pemberian materi pelajaran yang tidak memenuhi kepada apa yang dibutuhkan anak.[7]

Al Qur'an merupakan sumber inspirasi bagi berbagai disiplin ilmu pengetahuan. Tak terlepas pula pada sains informasi dan komunikasi. Pada Q.S Yasiin, ayat 12 Allah S.W.T berfirman yang artinya kurang lebih "Sungguh kami yang telah menghidupkan orang-orang yang mati dan kami catat apa yang telah mereka kerjakan dan bekas-bekas (yang mereka tinggalkan).Dan segala sesuatu kami perhitungkan dalam kitab yang nyata (Lauh Mahfudz)"(Syaamil Al Qur'an Terjemahan Per Kata halaman 440). Ayat tersebut di atas menjadi prinsip dasar pemikiran pada proses kerja Teknologi Informasi dan Komunikasi. Artinya setiap aplikasi atau input yang pernah kita akses tetap tersimpan dalam history, yang akhirnya dapat kita buka ataupun akses kembali.

Melalui teknologi informasi, hampir setiap segmen atau bidang kerja dapat diselesaikan dengan cepat, tepat dan akurat. Kelebihan-kelebihan yang dimiliki IT untuk menyelesaikan pekerjaan menjadikannya sebagai sebuah alternative utama. Begitupun pada sektor pendidikan, TIK saat ini bukanlah sebuah alternative tetapi sudah menjadi kebutuhan mendesak. Hal ini terbukti dengan dimasukkannya Teknologi Informasi dan Komunikasi (TIK) dalam struktur kurikulum mulai tahun pelajaran 2004/ 2005. Meski pada akhirnya dalam Kurikulum Tahun 2013 TIK dinyatakan tidak masuk pada struktur kurikulum.

Menurut Dr. Haris Iskandar Direktur Pembinaan SMA Direktorat Jendral Pendidikan Menengah kepada wartawan di FKIP Universitas Sebelas Maret (UNS) Solo, Sabtu (16/3). Meski dalam kurikulum 2013 tidak ada lagi mata pelajaran Teknologi Informatika dan Komputer (TIK), bukan gurunya akan menganggur. Guru TIK tetap akan memiliki peran penting. Mereka bisa dimasukkan dalam Pusat Teknologi Pendidikan yang ada di sekolah untuk membantu guru dalam mempersiapkan materi ajar. "Jadi guru TIK tetap akan berperan dalam kurikulum 2013," jelas Dr Haris Iskandar, [8]

Persoalannya, bagaimana agar mereka tetap mendapatkan tunjangan sertifikasi, sekarang tengah dipikirkan. Haris Iskandar menyadari belum seluruh guru mampu menyiapkan materi ajar dengan secara multi media. Padahal kurikulum 2013 adalah kurikulum teknologi yang pelaksanaan banyak mengandalkan kerja tim. Terkait dengan itu ia ingin menempatkan para guru TIK dalam sebuah wadah yang diberi nama Pusat Teknologi Pendidikan. Wadah inilah yang nantinya mempunyai peran penting dalam membantu para guru. (Sumber: krjogja.com)

SMP Islam Ungaran sebagai lembaga pendidikan formal beralamat di jalan Kauman Selatan nomor 1 Ungaran memberikan respek positif pada tumbuh kembangnya teknologi informasi. Berdasarkan profil sekolah, SMP Islam Ungaran saat ini dengan tenaga pendidik sejumlah 17 orang, pegawai 5 orang mengampu siswa sebanyak 234 orang dengan komposisi 76 orang siswa kelas VII, 80 orang siswa kelas VIII dan 78 orang siswa kelas IX. Pada struktur kurikulum yang diterapkan, Baca Tulis Al Qur'an adalah bagian materi Pendidikan Agama Islam yang diposisikan sebagai muatan lokal dengan alokasi waktu dua jam pembelajaran per minggu. Proses 
JURNAL ILMIAH KOMPUTER GRAFIS, Vol.13, No.1, Juli 2020, pp. 50 - 60

p-ISSN : 1979-0414(print)

e-ISSN : 2621-6256 (online)

http://journal.stekom.ac.id/index.php/pixel

pembelajaran muatan lokal Baca Tulis Al Qur'an mengedepankan aspek kognisi, afektif dan psikomotorik. Seperti halnya mata pelajaran lain, Baca Tulis Al Qur'an proses pembelajarannya masih menggunakan metode konvensional, belum sepenuhnya menggunakan fasilitas berbasis Teknologi Informasi tanda kutip komputer. Metode pembelajaran yang selama ini diterapkan di SMP Islam kurang responsif terhadap tumbuh kembangnya motivasi dan prestasi. Tenaga pendidik tanda kutip guru, masih mempolakan siklus pembelajaran textbook, dengar, baca, tulis dan penugasan. Hal ini terlihat dengan sikap belajar siswa yang ditunjukkan dengan cenderung malas, mengantuk dan tidak ada interaksi. Sehingga kemampuan siswa dalam baca tulis Al Qur'an masih rendah, terutama kaidah baca tulis A1 Qur'an.[9]

Dalam rekam data yang penulis peroleh melalui sebaran kuesioner tersaji data : sebanyak 69 responden ( siswa kelas VII ) tercatat $14 \%$ siswa mampu mengkhatamkan Iqra dan berlanjut ke mushaf Al Qur'an pada usia di bawah 10 tahun, sedangkan selebihnya $86 \%$ dalam usia lebih dari 10 tahun. Mereka yang yang masih aktif belajar sebesar $54 \%$, sisanya $46 \%$ sudah tidak aktif lagi. $41 \%$ siswa belum pernah mengenal adanya CD atau DVD pembelajaran Al Qur'an. Hal ini menunjukkan bahwa motivasi dan konsistensi untuk tetap belajar BTA pada siswa kelas VII tergolong rendah.

Kondisi tersebut bukan semata-mata karena daya serap siswa yang rendah, tetapi banyak faktor yang mempengaruhinya. Bisa jadi karena metode pembelajaran yang kurang tepat, model pembelajaran kurang menarik, atau mungkin karena faktor kesiapan siswa dakam menerima materi pelajaran yang kurang maksimal.

Namun dari beberapa faktor tersebut, berdasarkan pengamatan awal yang peneliti lakukan terdapat kecenderungan yang mengarah pada faktor metode pembelajaran yang harus disesuaikan. Dimana metode yang digunakan sebelumnya sebatas pada teori dan penugasan, sehingga peran aktif siswa kurang diperhatikan, akibatnya pembelajaran BTA boleh dikatakan stagnan dan belum memperlihatkan adanya peningkatan prestasi. Selanjutnya untuk mengetahui bagaimana kemampuan baca tulis Al Qur'an siswa SMP Islam Ungaran terutama dalam mempraktikkan bacaan ayat-ayat Al Qur'an dengan baik dan benar beserta cara menulisnya dipandang perlu mengetahui pemicu dan pemacunya.

Bertitik tolak dari hal tersebut, penulis memberanikan diri untuk mengadakan penelitian yang hasilnya akan penulis tuangkan dalam skripsi yang berjudul "Pengembangan Media Pembelajaran Baca Tulis Al Qur'an Kelas VII Berbasis Multimedia Untuk Meningkatkan Prestasi Belajar ( Studi Kasus Pada SMP Islam Ungaran )”.

\section{B. Perumusan masalah}

Bertolak dari latar belakang dan identifikasi masalah di atas, maka penulis merumuskan permasalahan dalam penelitian sebagai berikut:

1. Apakah metode pembelajaran yang diterapkan oleh tenaga pendidik saat ini telah efektif untuk meningkatkan prestasi belajar Baca Tulis Qur'an di SMP Islam Ungaran ?

2. Perangkat pendukung metode pembelajaran yang bagaimanakah agar terjadi pembelajaran aktif, kreatif, interaktif dan optimal sehingga secara efektif mampu meningkatkan prestasi belajar BTA siswa kelas VII di SMP Islam Ungaran?

3. Bagaimana menyusun dan menerapkan perangkat pendukung metode pembelajaran yang secara efektif mampu meningkatkan prestasi belajar BTA di SMP Islam Ungaran?

\section{Batasan Masalah}

1. Obyek penelitian adalah siswa kelas VII SMP Islam Ungaran;

2. Mata pelajaran yang diteliti adalah Mata Pelajaran Baca Tulis Al Qur'an kelas VII

3. Materi dan indikator yang diteliti adalah kemampuan siswa dalam membaca Al Qur'an dengan tartil dan kemampuan siswa dalam menulis huruf hijaiyah sesuai dengan kaidah penulisan yang baik dan benar,

4. Perangkat lunak yang dikembangkan menjadi media pembelajaran adalah : Macromedia Director MX 2004

\section{Tujuan dan manfaat}

Penerapan tujuan penelitian merupakan langkah awal yang penting dilakukan sebelum memulai penelitian. Karena dengan ditetapkannya tujuan, langkah-langkah penelitian menjadi lebih terarah dan jelas.

1. Berdasarkan perumusan dan pembatasan masalah yang ada, bertujuan :

a) Memberi solusi metode pembelajaran yang mampu menggairahkan minat belajar Baca Tulis Al Qur'an bagi siswa kelas VII SMP Islam Ungaran khususnya ataupun para santri di TPQ pada umumnya;

b) Perangkat bantu pembelajaran yang efektif meningkatkan prestasi belajar Baca Tulis Al Qur'an bagi siswa kelas VII SMP Islam Ungaran secara khusus ataupun para santri di TPQ pada umumnya

2. Manfaat berdasarkan perumusan dan pembatasan masalah yang ada: 
JURNAL ILMIAH KOMPUTER GRAFIS, Vol.13, No.1, Juli 2020, pp. 50 - 60

p-ISSN : 1979-0414(print)

e-ISSN : 2621-6256 (online)

http://journal.stekom.ac.id/index.php/pixel

a) Sebagai upaya mencapai keberhasilan pembelajaran yang secara efektif mampu meningkatkan prestasi belajar Baca Tulis Al Qur'an bagi siswa kelas VII SMP Islam Ungaran secara khusus ataupun para santri di TPQ pada umumnya

b) Untuk meningkatan kefasihan dan kemampuan siswa kelas VII SMP Islam Ungaran mampu bersaing dengan sekolah lain

\section{E. Kajian Teori}

\section{Pengembangan}

Edwin B. Flippo mendefinisikan pengembangan sebagai berikut : "Pendidikan adalah berhubungan dengan peningkatan pengetahuan umum dan pemahaman atas lingkungan kita secara menyeluruh", Sedangkan Andrew F. Sikula mendefinisikan pengembangan sebagai berikut : "Pengembangan mengacu pada masalah staf dan personel adalah suatu proses pendidikan jangka panjang menggunakan suatu prosedur yang sistematis dan terorganisasi dengan mana manajer belajar pengetahuan konseptual dan teoritis untuk tujuan umum"..

\section{Media Pembelajaran}

Media berasal dari bahasa latin merupakan bentuk jamak dari "Medium" yang secara harfiah berarti "Perantara" atau "Pengantar" yaitu perantara atau pengantar sumber pesan dengan penerima pesan. Beberapa ahli memberikan definisi tentang media pembelajaran. Schramm (1977) mengemukakan bahwa media pembelajaran adalah teknologi pembawa pesan yang dapat dimanfaatkan untuk keperluan pembelajaran.

Sementara itu, Briggs (1977) berpendapat bahwa media pembelajaran adalah sarana fisik untuk menyampaikan isi/materi pembelajaran seperti : buku, film, video dan sebagainya. Sedangkan, National Education Associaton(1969) mengungkapkan bahwa media pembelajaran adalah sarana komunikasi dalam bentuk cetak maupun pandang-dengar, termasuk teknologi perangkat keras. Dari ketiga pendapat di atas disimpulkan bahwa media pembelajaran adalah segala sesuatu yang dapat menyalurkan pesan, dapat merangsang fikiran, perasaan, dan kemauan peserta didik sehingga dapat mendorong terciptanya proses belajar pada diri peserta didik.

Brown (1973) mengungkapkan bahwa media pembelajaran yang digunakan dalam kegiatan pembelajaran dapat mempengaruhi terhadap efektivitas pembelajaran. Pada mulanya, media pembelajaran hanya berfungsi sebagai alat bantu guru untuk mengajar yang digunakan adalah alat bantu visual. Sekitar pertengahan abad $\mathrm{Ke}-20$ usaha pemanfaatan visual dilengkapi dengan digunakannya alat audio, sehingga lahirlah alat bantu audio-visual. Sejalan dengan perkembangan ilmu pengetahuan dan teknologi (IPTEK), khususnya dalam bidang pendidikan, saat ini penggunaan alat bantu atau media pembelajaran menjadi semakin luas dan interaktif, seperti adanya komputer dan internet.

3. Al Qur'an

Ta'riful Qur'an

Menurut bahasa, "Qur'an” berarti “bacaan”, pengertian seperti ini dikemukakan dalam Al-Qur'an sendiri yakni dalam surat Al-Qiyamah, ayat 17-18:

"Sesungguhnya mengumpulkan Al-Qur'an (di dalam dadamu) dan (menetapkan) bacaannya (pada lidahmu) itu adalah tanggungan kami. (Karena itu), jika kami telah membacakannya, hendaklah kamu ikuti bacaannya".

Adapun menurut istilah, Al-Qur'an berarti: “Kalam Allah yang merupakan mu'jizat yang diturunkan kepada nabi Muhammad, yang disampaikan secara mutawatir dan membacanya adalah ibadah".

Al-Manquulu bi-ttawaatir

Al-Qur'an ditulis dalam mushaf-mushaf dan disampaikan kepada kita secara mutawatir (diriwayatkan oleh banyak orang), sehingga terpelihara keasliannya. Berikut sekilas sejarah pemeliharaan Al-Qur'an sejak masa Nabi hingga pembukuannya seperti sekarang:

Pada masa Nabi Al-Qur'an dihafal dan ditulis di atas batu, kulit binatang, pelapah tamar dan apa saja yang bisa dipakai untuk ditulis. Kemudian setahun sekali Jibril melakukan repetisi (ulangan), yakni dengan menyuruh Nabi memperdengarkan Al-Qur'an yang telah diterimanya.

\section{Multimedia}

Panduan untuk mengetahui multimedia harus dimulai dengan definisi atau pengertian multimedia. Dalam industri elektronika, multimedia adalah kombinasi dari komputer dan video (Rosch, 1996) atau multimedia secara umum merupakan kombinasi tiga elemen yaitu, suara, gambar dan teks (Mc Cormick, 1996) atau multimedia adalah kombinasi dari paling sedikit dua media input atau output dari data, media ini dapat berupa audio (suara,musik), animasi, video, teks, grafik dan gambar (Turban dkk, 2002) atau 
JURNAL ILMIAH KOMPUTER GRAFIS, Vol.13, No.1, Juli 2020, pp. 50 - 60

p-ISSN : 1979-0414(print)

e-ISSN : 2621-6256 (online)

http://journal.stekom.ac.id/index.php/pixel

multimedia merupakan alat yang menciptakan presentasi yang dinamis dan interaktif yang mengkombinasikan teks, grafik, animasi, audio dan gambar video (Robin dan Linda, 2001).

Definisi lain dari multimedia yaitu dengan menempatkannya dalam konteks, seperti yang dilakukan oleh Hoftsteter (2001), multimedia adalah pemanfaatan komputer untuk membuat dan menggabungkan teks, grafik, audio, video dan animasi dengan menggabungkan link dan tool yang memungkinkan pemakai melakukan navigasi, berinteraksi, berkreasi dan berkomunikasi.

Dalam definisi ini terkandung empat komponen penting multimedia.

a) Pertama, harus ada komputer yang mengkoordinasi apa yang dilihat dan didengar yang berinteraksi dengan kita.

b) Kedua, harus ada link yang menghubungkan kita dengan informasi.

c) Ketiga, harus ada alat navigasi yang memandu kita, menjelajah jaringan informasi yang saling terhubung.

d) Keempat, multimedia menyediakan tempat kepada kita untuk mengumpulkan, memproses dan mengkomunikasikan informasi dan ide kita sendiri. Jika salah satu komponen tidak ada, maka bukan multimedia dalam arti luas namanya. Misalnya jika tidak ada komputer untuk berinteraksi maka itu namanya media campuran, bukan multimedia. Jika tidak ada link yang menghadirkan sebuah struktur dan dimensi, maka namanya rak buku, bukan multimedia. Kalau tidak ada navigasi yang memungkinkan kita memilih jalannya suatu tindakan maka itu namanya film, bukan multimedia. Demikian juga jika kita tidak mempunyai ruang untuk berkreasi dan menyumbangkan ide sendiri, maka namanya televisi, bukan multimedia. Dari definisi diatas, maka multimedia ada yang online (internet) dan multimedia yang offline (tradisional).

\section{Prestasi Belajar}

Beberapa Pakar berpendapat tentang pengertian prestasi adalah sebagai berikut, Muray (1990 : 290) berpendapat bahwa prestasi adalah mengatasi hambatan, melatih kekuatan, berusaha melakukan sesuatu yang sulit dengan baik dan secepat mungkin.

Sementara itu menurut Abdul Qohar, prestasi adalah segala sesuatu yang telah dapat diciptakan, hasil pekerjaan, hasil yang menyenangkan hati yang diperoleh dengan jalan keuletan kerja".

Tidak jauh berbeda dari abdul Qohar, Djamarah mendefinisikan Prestasi adalah hasil dari suatu kegiatan yang telah dikerjakan, dicipatkan, baik secara individual maupun kelompok.

Dengan demikian dapat dismpulkan bahwa pengertian prestasi segala sesuatu yang ada yang diperoleh dengan cara atau proses mengatasi, mengerjakan, atau melatih dengan baik yang dilakukan oleh individu maupunkelompok.

Untuk definisi belajar juga diambil pendapat para pakar antara lain, Witherington, dalam buku Educational Pychology mendefinisikan Belajar adalah suatu perubahan didalam kepribadian yang menyatakan diri sebagai suatu pola baru dari pada reaksi yang berupa kecakapan, sikap, kebiasaan, kepandaian, atau suatu pengertian. ( Drs. Ngalim Purwanto, MP, Psikologi Pendidikan, Remaja Rosdakarya)

Cronbach berpendapat bahwa Belajar adalah memperlihatkan perubahan dalam perilaku sebagai hasil daripengalaman.

Menurut Morgan Belajar adalah setiap perubahan yang relatif menatap dalam tingkah laku yang terjadi sebagai suatu hasil dari latihan atau pengalaman.

Dari pendapat tersebut dapat diambil pemahaman bahwa belajar bukan hanya berupa kegiatan mempelajari suatu mata pelajaran secara formal, tetapi belajar juga merupakan masalah setiap orang, hampir setiap kecakapan, ketrampilan, pengetahuan, kebiasaan, kegemaran dan sikap manusia terbentuk, dimodifikasi dan berkembang karena belajar, kegiatan belajar dapat terjadi dimana-mana baik dilingkungan keluarga, masyarakat, lembaga pendidikan formal disekolah.

6. SMP Islam Ungaran

Lembaga pendidikan tingkat lanjutan pertama yang berstatus Terakreditasi A beralamat di jalan Kauman Selatan no. 1 Ungaran, berdasarkan ijin operasional didirikan pada tanggal 1 Januari 1978. Nomor Statistik Sekolah : 202032214045 dan Nomor Pokok Sekolah Nasional : 20320205; ( Profil SMP Islam Ungaran, 10 November 2012)

\section{F. Kajian Penelitian yang relevan}

Untuk melengkapi khasanah referensi pendukung penelitian ini, penulis sengaja melakukan pendekatan pada beberapa jurnal ilmiah sebagai berikut : 
JURNAL ILMIAH KOMPUTER GRAFIS, Vol.13, No.1, Juli 2020, pp. 50 - 60

p-ISSN : 1979-0414(print)

e-ISSN : 2621-6256 (online)

http://journal.stekom.ac.id/index.php/pixel

Beberapa catatan penting yang menjadi dasar pemikiran penulis untuk membuat media pembelajaran berbasis multimedia, dengan mempertimbangkan (a) kesederhanaan, artinya memberikan kemudahan siswa untuk mengoperasionalkan (b) personal, berarti siswa mampu berinteraksi dengan atau tanpa didampingi guru (c) cepat, artinya kinerja software tidak lamban (d) dibutuhkan oleh siswa di semua tingkat pendidikan atau masyarakat umum (e) efisien, artinya tidak mengeluarkan banyak biaya (f) media dakwah, artinya sebagai perangkat bantu untuk menyampaikan dakwah dalam upaya pemberantasan buta aksara Qur'an

\section{G. Kerangka Pemikiran}

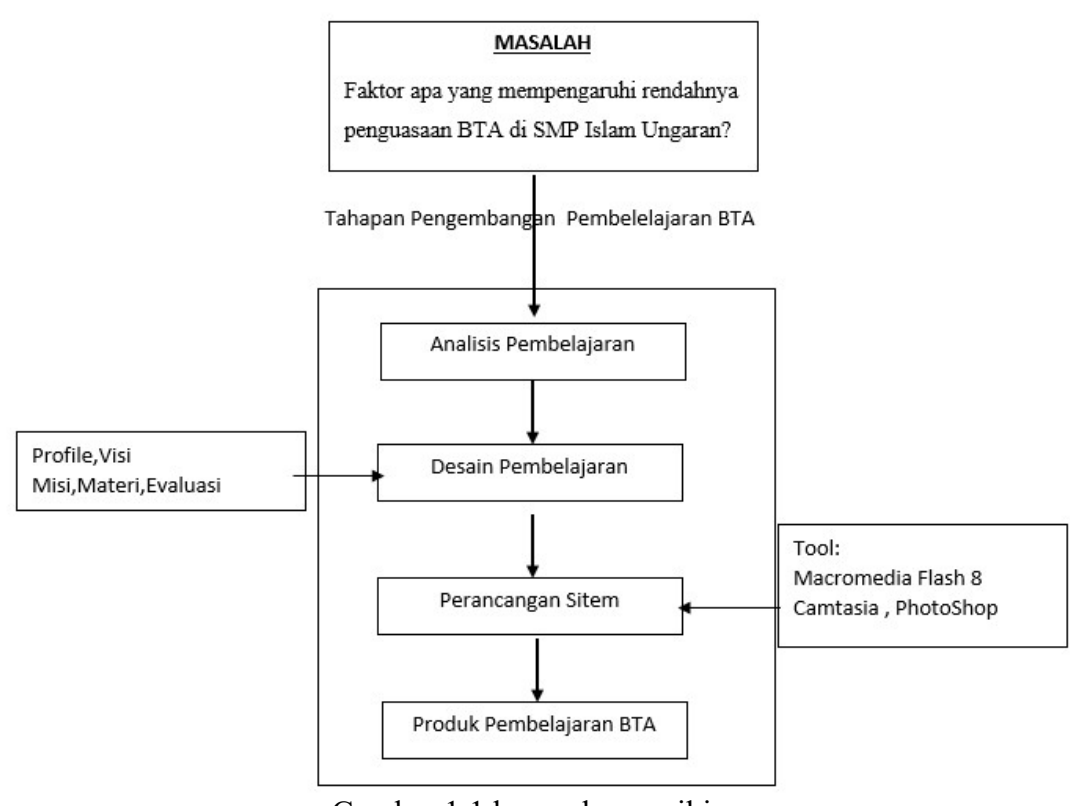

Gambar 1.1 kerangka pemikiran

\section{H. Model Pengembangan}

Model Pengembangan Sistem Pembelajaran Menurut Dick dan Carey

Model pengembangan sistem pembelajaran menurut Dick dan Carey mirip dengan model yang dikembangkan oleh Kemp, namun masih ditambah lagi dengan komponen melaksanakan analisis pembelajaran. Model pengembangan menurut Dick dan Carey dapat disajikan dalam gambar di bawah ini [10] 


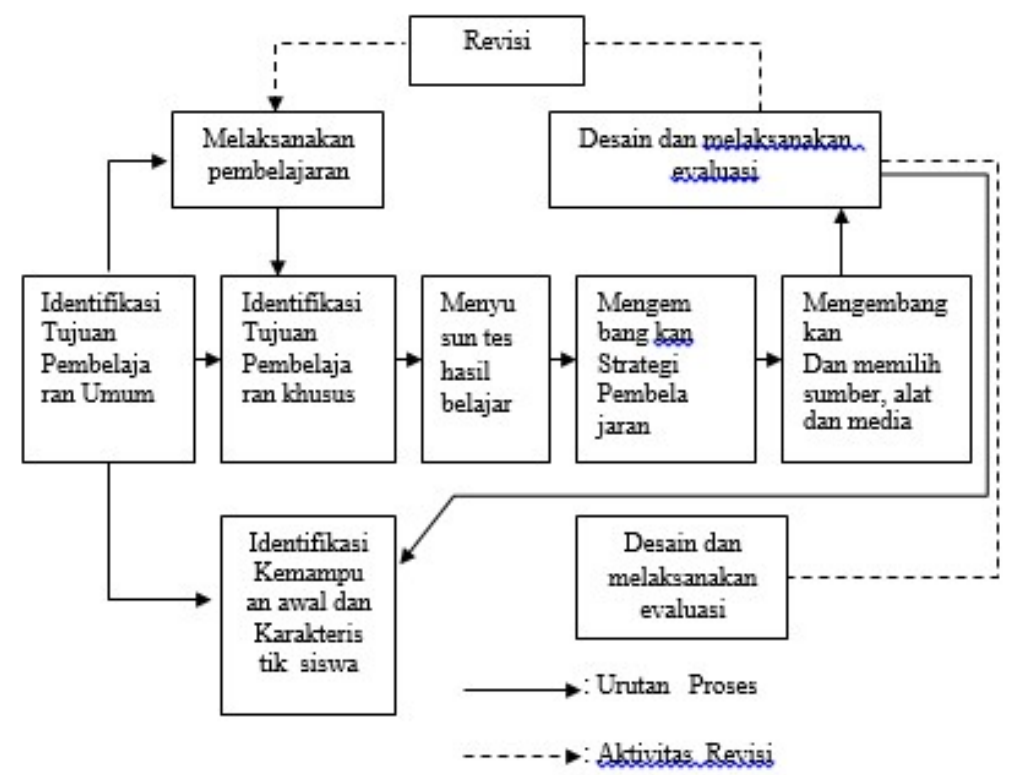

Gambar 2 Model pengembangan sistem pembelajaran

Model pengembangan sistem pembelajaran di atas menjadi acuan penulis dalam melakukan penelitian. Langkah-langkah pengembangan secara garis besar penulis uraikan sebagai berikut :

1. Mengidentifikasi Tujuan Pembelajaran

Penulis mengidentifikasi tujuan pembelajaran berdasarkan Standar Kompetensi yang terangkum pada silabus Baca Tulis Al Qur'an kelas VII.

Karena terdapat banyak Standar Kompetensi, maka penulis sengaja membingkainya dalam kompetensi baca dan tulis sebagai berikut :

a. Standar Kompetensi 1 : Memahami makhorijul khuruf dan menerapkan dalam praktik membaca Al-

Qur'an dengan baik dan benar

b. Standar Kompetensi 4 : Memahami kaidah menulis huruf-huruf Al-Qur'an dengan baik dan benar

2. Melaksanakan Pembelajaran

Pembelajaran dilaksanakan setelah memahami hasil identifikasi Tujuan Pembelajaran Umum dalam hal ini mengacu pada Standar Kompetensi yang telah ditentukan.

3. Identifikasi Tujuan Pembelajaran khusus

Tujuan pembelajaran khusus merupakan sub kegiatan Standar kompetensi yang disebut Kompetensi dasar. Sebagaimana yang tersaji dalam Silabus, maka kompetensi dasar yang Penulis gunakan dalam penelitian ini adalah :

a. Kompetensi Dasar 1.1 : Siswa mampu menjelaskan makhorijul huruf dengan baik dan benar

b. Kompetensi Dasar 1.2 : Siswa mampu menerapkan makhorijul huruf dengan baik dan benar ;

c. Kompetensi Dasar 4.1 : Siswa mampu menjelaskan kaidah menulis huruf huruf Al Qur'an lepas berharokat dengan baik dan benar ;

d. Kompetensi Dasar 4.2 : Siswa mampu menerapkan kaidah menulis huruf huruf Al Qur'an lepas berharokat dengan baik dan benar ;

e. Kompetensi Dasar 4.3 : Siswa mampu menjelaskan kaidah menulis huruf huruf Al Qur'an bersambung berharokat dengan baik dan benar;

f. Kompetensi Dasar 4.4 : Siswa mampu menerapkan kaidah menulis huruf huruf Al Qur'an bersambung berharokat dengan baik dan benar.

4. Menyusun tes hasil belajar

Ketika pembelajaran berlangsung, perlu segera dipikirkan penyusunan tes hasil belajar. Hal ini bertujuan untuk mengetahui ketercapaian pembelajaran.

5. Mengembangkan strategi pembelajaran

Tes hasil belajar mengindikasikan indikator pencapaian kompetensi. Artinya hasil tes sangat dimungkinkan sebagai motivasi untuk mengembangkan strategi pembelajaran.

6. Mengembangkan dan memilih sumber alat dan media 
JURNAL ILMIAH KOMPUTER GRAFIS, Vol.13, No.1, Juli 2020, pp. 50 - 60

p-ISSN : 1979-0414(print)

e-ISSN : 2621-6256 (online)

http://journal.stekom.ac.id/index.php/pixel

Suasana pembelajaran yang efektif mendorong keberhasilan pembelajaran sehingga mampu mengubah pola pikir dan pola tindak peserta didik dipengaruhi juga oleh pengembangan dan pemilihan sumber alat serta media yang digunakan ;

7. Desain dan melaksanakan evaluasi

Proses ini menjadi penting ketika pembelajaran diawali dengan menyusun desain dan mengakhirinya dengan melaksanakan evaluasi.

Namun, apabila setelah berlangsungnya proses ini ternyata kurang atau bahkan tidak menunjukkan adanya perubahan positif, maka perlu diadakan perbaikan. Revisi atau perbaikan ini dimulai pada proses awal yaitu Identifikasi Tujuan Pembelajaran khusus;

8. Identifikasi kemampuan awal dan karakteristik siswa

Proses ini dilaksanakan untuk mengetahui seberapa paham siswa pada materi pembelajaran dan motivasi belajar peserta didik

\section{Hasil dan pembahasan}

Untuk mendukung hasil penelitian diperlukan mediator berupa produk yang dikembangkan.

Dalam penelitian ini, penulis menggunakan produk yang dikembangkan berbentuk format media pembelajaran berbasis multimedia.

a) Spesifikasi produk yang penulis kembangkan adalah :

1) Jenis produk : Media Pembelajaran;

2) Basis : Multimedia

3) Media operasional : CD atau DVD ;

4) Sistim Operasi : Windows 7; Windows XP

5) Sistim aplikasi : : Macromedia Flash 8; Camtasia, Adobe Photoshop CS 3

b) Perancangan

\section{Halaman Menu Utama}

Bentuk tampilan halaman utama dalam metode pembelajaran baca tulis alqur'an yang terdapat beberapa menu navigasi yang simple dan memudahkan dalam menjalankannya

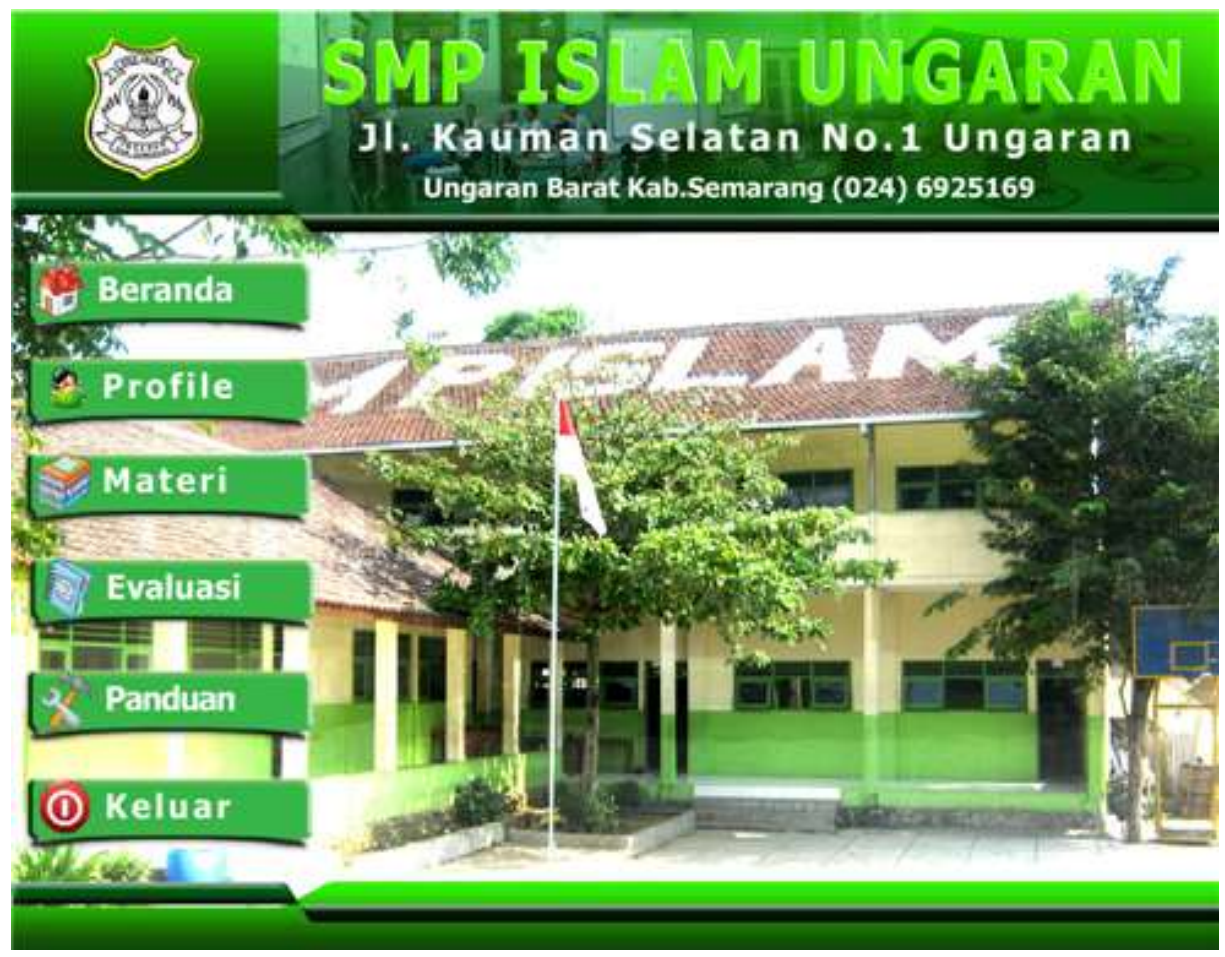

Gambar 3 form halaman utama

JURNAL ILMIAH KOMPUTER GRAFIS, Vol.13, No.1, Juli 2020, pp. 50 - 60 
JURNAL ILMIAH KOMPUTER GRAFIS, Vol.13, No.1, Juli 2020, pp. 50 - 60

p-ISSN : 1979-0414(print)

e-ISSN : 2621-6256 (online)

http://journal.stekom.ac.id/index.php/pixel

\section{Hamalan menu materi}

Halaman materi ini terdiri dari 16 materi pembelajaran baca tulis alqur'an baik cara penulisan tadjid dan cara pembacaannya

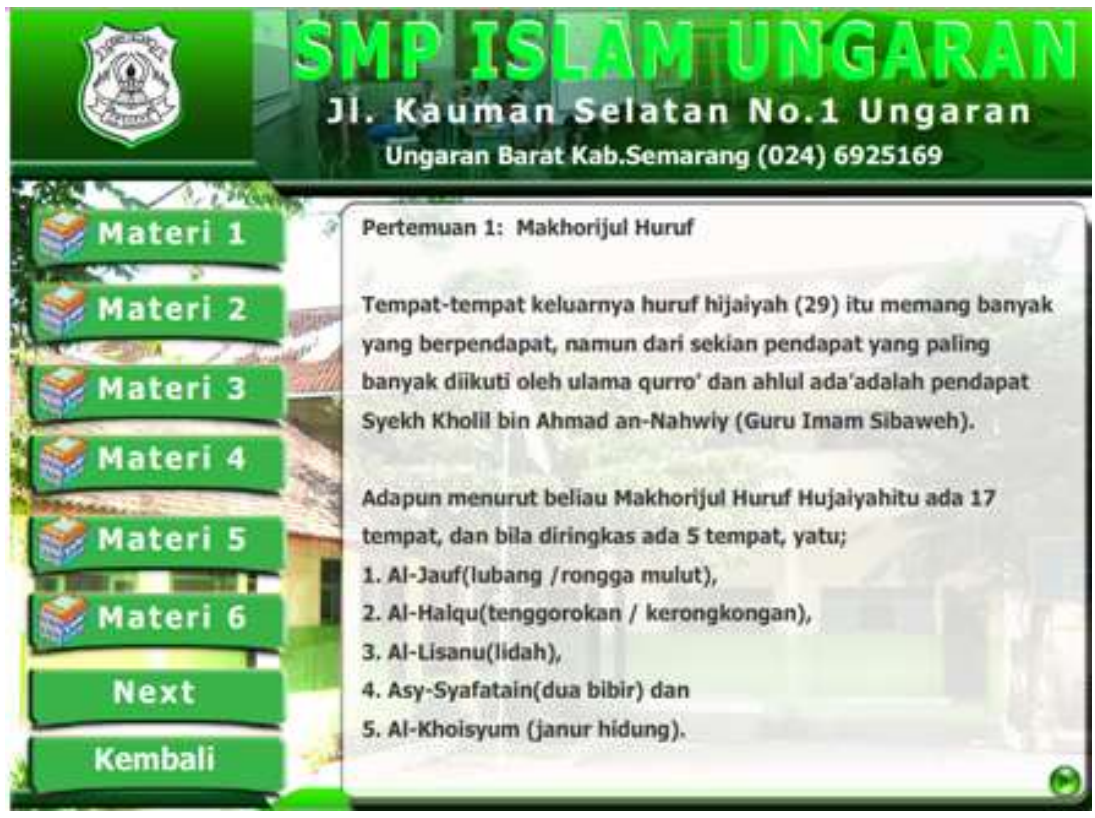

Gambar 4 form materi baca tulis alqur'an

\section{Halaman evaluasi}

Halaman evaluasi menampilkan bentuk soal multiple choise dimana terdapat 4 jawaban pilihan , evaluasi ini ini bertujuan untuk menguji sampai dimana tingkat pemahaman siswa terdapat pembelajaran yang di pelajarinya

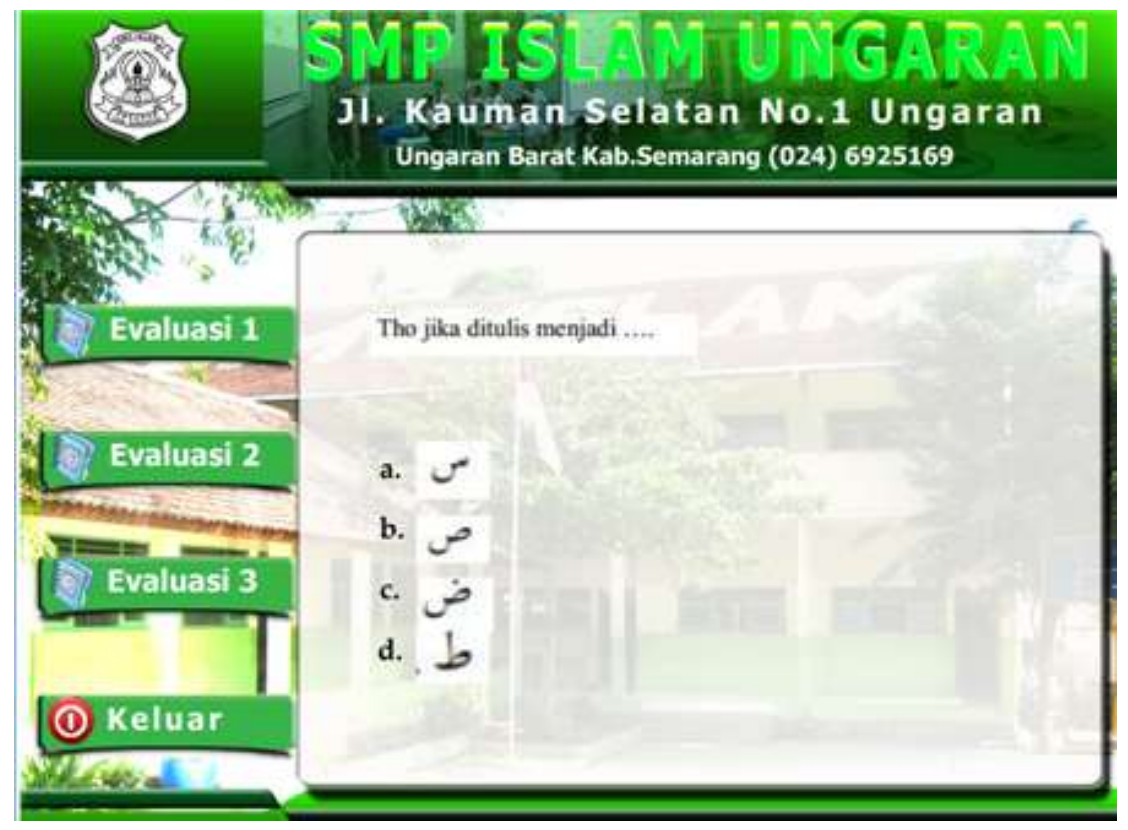

Gambar 5 form evaluasi pembelajaran baca tulis alqur'an

JURNAL ILMIAH KOMPUTER GRAFIS, Vol.13, No.1, Juli 2020, pp. 50 - 60 
JURNAL ILMIAH KOMPUTER GRAFIS, Vol.13, No.1, Juli 2020, pp. 50 - 60

p-ISSN : 1979-0414(print)

e-ISSN : 2621-6256 (online)

http://journal.stekom.ac.id/index.php/pixel

\section{J. Simpulan}

Penerapan Metode pembelajaran Baca-Tulis Al-Qur'an di SMP Islam Ungaran yang dijadikan sample oleh peneliti sebagai panduan belajar mengajarnya melalui beberapa tahap, yaitu:

Kegiatan proses belajar mengajar dengan menggunakan metode klasikal,menggunakan metode individual, menggunakan metode semi klasikal.Penilaian Pembelajaran diperoleh dari tes evaluasi yang dilaksanakan dengan Metode yang diterapkan santri dalam meningkatkan pemahaman baca tulis Al-Qur'an pada SMP Islam Ungaran sudah menunjukkan hasil yang positif. lebih baik lagi dipertahankan dan ditingkatkan lagi dengan cara mengikutsertakan para pengajar SMP Islam Ungaran.

\section{K. Daftar Pustaka}

1. Depag RI, Al-Qur'an dan Terjemahnya, Jakarta: 1971, hlm.645

2. Ahmad Syarifuddin, Mendidik Anak Mambaca, Menulis, dan Mencintai Al-Qur'an, Jakarta:Gema Insani, 2004, hlm. 16

3. Depdiknas, Kamus Besar Bahasa Indonesia, Jakarta: Balai Pustaka: 2005, hlm. 740.

4. Zakiah Darajat, Metodik Khusus Pengajaran Agama Islam, Jakarta: Bumi Aksara, 2004, h. 92.

5. Imam Barnadib, Dasar-Dasar Pendidikan Perbandingan (Yogyakarta: Institut Press, IKIP Yogyakarta, 1988) hal. 29-30

6. M. Dahlan, Kamus Ilmiah Populer. Surabaya, Arkola, 1994. Hal 633

7. Armai Arief. Pengantar Ilmu Dan Metodologi Pendidikan Islam . Jakarta : Ciputat Pers, 2002. hlm 1

8. Dr. Haris Iskandar,Materi har kurikulum 2013

9. Alisuf Sabri, Buletin Mimbar Agama dan Budaya (Jakarta: IAI, 1991), hal 14

10. Dick dan Carey, Model Pengembangan Sistem Pembelajaran 